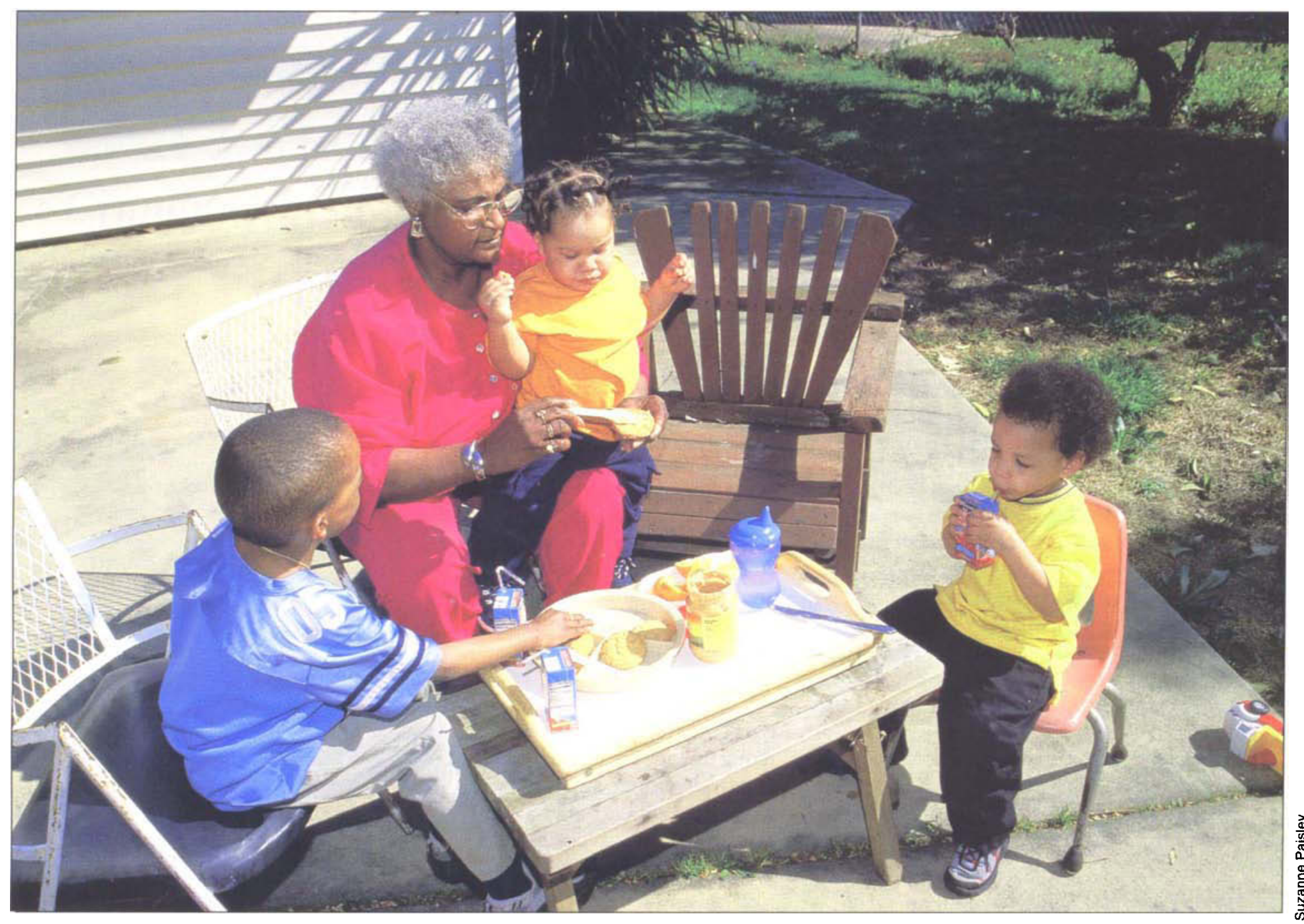

Nearly a half-million California children were living in grandparent-headed households in 1990, and the rates have been increasing. Lula Jones, 69, cares for four of her greatgrandchildren in Sacramento. She shares a snack with, left to right: Omari Lee, 4;

Numbers rising... Deandre Jones, 20 months; and Giovani Griffin, 2.

\title{
Grandchildren raised by grandparents a troubling trend
}

\section{Mary L. Blackburn}

This study was conducted in response to requests for demographic and needs data on children living with grandparents in California and elsewhere. The 1990 U.S. Census reported that in California, at least 493,080 children under age $18(6.4 \%)$ lived in households headed by their grandparents. In Alameda County, for example, 22,783 children lived with their grandparents and, of these, about 9,330 (41\%) were un- der 6 years old. Grandparents raising their grandchildren is not a new phenomenon, but the conditions under which some assume primary parenting responsibilities are a growing concern. Custodial grandparents may have multiple health problems and experience severe stress when confronted by the attendant costs and responsibilities. The grandchildren often have emotional, learning and physical disabilities, and many live in poverty. This study describes the demographic distribution of grandchildren living in grandparent households in California, standardizes prevalence rates by county and sets priorities for health and human service needs of grandparents and the grandchildren under their care. We recommend program planning within UC Cooperative Extension to respond to the educational and training needs of older caregivers. 


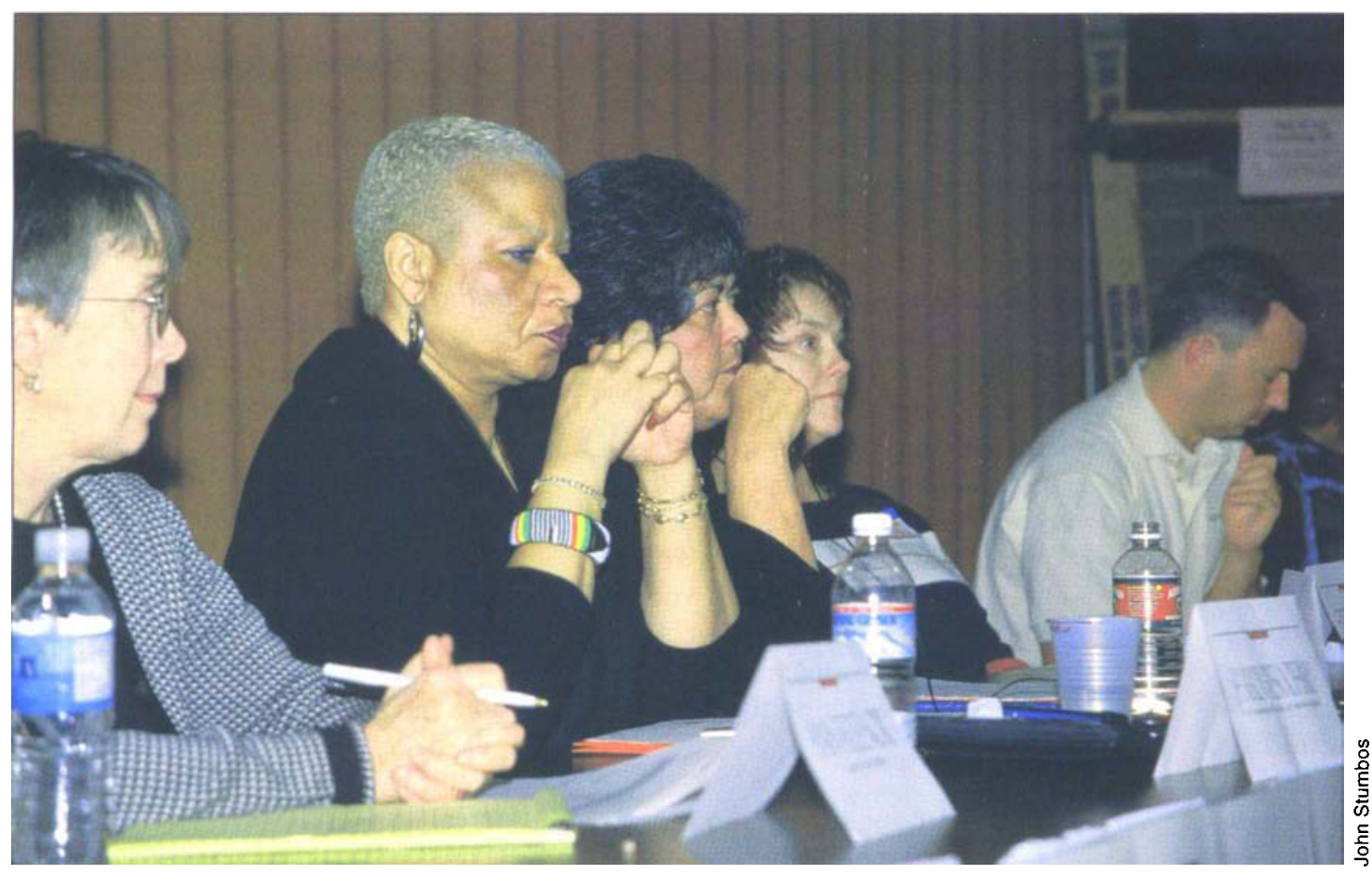

Public awareness of grandparenting has increased. At a recent Sacramento conference, service providers heard from grandparents about their needs and concerns. Left to right, Ann Fleener, Senior Legal Services Hotline; Sharron

Treskunoff Bailey, U.S. Department of Housing and Urban Development; Teresa Contreras, California Kinship Policy Unit; Stephanie Zach, Sacramento AARP; and Michael Joyce, UC Davis physician and radio host.

$\mathrm{T}$ The 1990 U.S. Census reported that at least $6.4 \%$ of all California children under 18 , or 493,080 children, lived in households headed by their grandparents. That represents $11.8 \%$ of such grandchildren nationwide. This is not a new phenomenon, but the emotional, physical and financial conditions under which many caregivers assumed primary parenting roles generated widespread concerns in the 1990s. Many of the custodial grandparents have multiple health problems and are devastated by the added cost and responsibilities. Many grandchildren they parent have emotional, learning and physical disabilities, and live in poverty.

The 1990 U.S. Census showed a 20year increase of about $53 \%$ in the national prevalence rate of children under age 18 living with their grandparents. The rates have been steadily rising from about $3.2 \%$ in 1970 , to $3.6 \%$ in 1980 , to $4.9 \%$ in 1990 . Upward trends were observed in three major population groups (whites, blacks and Hispanics) for which 1970 comparative data were available (Saluter 1994).

U.S. Census 1998 Current Population Survey (CPS) data established that primary grandparent caregivers exist among all socioeconomic and ethnic groups. However, they were more prevalent among poor people living in or near urban centers. The ethnic distribution of primary grandparent households nationwide was about $68 \%$ white, 29\% black, 10\% Hispanic, $2 \%$ Asian-Pacific Islander and 1\% Native American (Chalfie 1995).

By definition, "grandparent-headed households" may or may not include the children's parents, who may or may not be contributing financially and emotionally to the support of the children (fig. 1). The terms "prevalence rates" or "youth-based prevalence rates" refer to the percentage of children under 18 living in grandparentheaded households. Furthermore, many more children are living with kinship caregivers other than grandparents, such as aunts, uncles, cousins or great-grandparents.

Grandparenting in California first became a visible research issue after the study by Linda Burton, for her doctoral thesis in 1985 at the University of Southern California. Burton (1991, 1992) examined teen pregnancy in relation to multigenerational grandparenting attitudes and issues among black families. Many grandparents were relatively young them- selves and resented the imposition on their own lives.

Two subsequent studies with black grandparents in Alameda County pointed to the financial and emotional traumas grandparents experienced while raising a second, and sometimes a third family. Minkler and Roe (1993) focused on African-American grandmothers forced into primary caregiver roles because of crack cocaine. Among the grandmothers interviewed, $69 \%$ who cared for one or more children under age 5 said their incomes were inadequate. About $78 \%$ reported a decrease in income after becoming primary caregivers. Poe (1992) highlighted the anger, embarrassment and fear felt by grandparents who, to care for their grandchildren, sacrificed goals, social life, expected leisure time and financial status while also suffering a decline in physical health.

Before the publicized results of those studies, much of the local data were gleaned from one-on-one contacts with grandparents, such as observations made in schools and Oakland's senior centers. The Oakland Department on Aging surveyed the Oakland Head Start program and found that elder Americans parented $20 \%$ of these preschool children. Anec- 
dotal stories were considered to be personal evidence that something significant was amiss. The fabric of information woven from these bits and pieces of human drama was alarming and unsettling to some public officials and service providers. For example, one grandmother, who lost her job because she became a caregiver for her three grandsons, said the best she could do sometimes was to hold them tight and say, "Grandma loves you!"

\section{UCCE data collection}

During the early 1990s, UC Cooperative Extension (UCCE) was often asked by senior service providers to supply data on the number, location and particular needs of the children. But the answers were not readily available because state-specific census data had not been reviewed and presented for program planning purposes. UCCE Alameda County compiled information from the 1990 U.S. Census database to determine California's potential client base of infants and minor children, and established county-by-county rates of the prevalence of children living in grandparent-headed households. Several needs assessment surveys and interactive group activities were also conducted to: (1) identify health and human services needs of grandparents and grandchildren; (2) establish priorities for caregiver training, education and support services; and (3) identify key public policy issues.

Preliminary data revealed a constellation of problems faced by primary grandparent caregivers. Many who lived in urban centers were dealing with factors associated with the children's substance-abusing parents, such as unemployment, homelessness, incarceration, homicides, neglect, abuse and lack of child-care services (Jendrek 1994; Ginchild 1995; Minkler and Fuller-Thompson 1999). Grandparents who became primary caregivers often reported that they had no choice if they were to prevent their grandchildren from becoming wards of the courts. However, such decisions can incur legal difficulties as well as social and economic ones. For ex- ample, if social service agencies declare parents "unfit," grandparents may have no legal standing to remain primary caregivers.

The picture of the grandparent caregiver became more complete as data were collected from four sources:

\section{- The 1990 U.S. Census. The}

Alameda County Planning Department searched the 1990 statespecific census database for California counties; the Census Bureau provided data for each state. UCCE Alameda County calculated youthand population-based grandchildren prevalence rates for California's counties using the following formulas:

Children under 18 years in grandparent households

All children under 18 years in each county

Children under 18 years in grandparent households

Total population in each county

- Alameda County workshops survey. Under its "Grandparents Are People Too" program, UCCE conducted needs assessment surveys with 98 grandparent participants attending a series of workshops and trainings in 1994 and 1995. The surveys documented the number of children these caregivers parented, and revealed the health and human services needs of the caregivers and their grandchildren. This group was $68 \%$ black, $15 \%$ white, $8 \%$ Hispanic, $2 \%$ Native American and $7 \%$ other.

- Sacramento conference survey. In March 1996, at a grandparent conference called "Raising Your Children's Children in the 1990s," the Sacramento 21 Community Partnership/Community Services Planning Council conducted brief needs assessment surveys with 121 caregiver participants from 24 California counties. The participants' ethnicities were $60.5 \%$ white, $16.5 \%$ black, 14\% Hispanic/Latino, 5\% Asian-Pacific Islander and 4\% Native American. The surveys docu- mented why these grandparents became primary caregivers, their grandparenting responsibilities, the cost of grandparenting, the needs of the grandchildren, and the education and support priorities of grandparents.

- Sacramento focus groups. At the same 1996 conference, UCCE Alameda County conducted two interactive focus groups with 58 grandparents, during which experiences were discussed.

\section{Increased public awareness}

In 1989, Oakland spearheaded one of the first efforts to promote public awareness of grandparenting in the San Francisco Bay Area and throughout California. Oakland formed a coalition called Families United Against Crack Cocaine (FUACC) and secured federal funds for its 2-year demonstration Intergenerational Families Peer Counseling Project for elder grandparents who were assuming primary parenting duties. The project demonstrated the need for education and training on health and wellness, parenting, guardianship and other legal issues, as well as the need for stress reduction techniques and help accessing community resources. It also emphasized the need to train children in intergenerational communication, self-esteem and peer support. Widespread press coverage of these efforts helped focus local and national attention on grandparenting.

UCCE Alameda County served on Oakland's FUACC Advisory Council and its Families Peer Counseling training team. The team provided more than 50 elder caregivers with 30 hours of education and training on legal issues, health, parenting, stress management and resource identification. After this demonstration project ended in 1992, UCCE initiated its unfunded Grandparents Are People Too education and research program to address the education needs of grandparent caregivers and to do this research.

\section{Rates on the rise}

National prevalence rates. According to the 1990 census, children 
living in grandparent households within each state, as a percentage of the state's total population (the population-based grandchildren prevalence rate), ranged from a high of $4.5 \%$ in Washington, D.C., to lows of $0.48 \%$ to $0.57 \%$ in North Dakota and Minnesota, respectively.

Children living in grandparentheaded households comprised $4.9 \%$ of all children under age 18 in the United States. With $23 \%$ of its children under 18 living in grandparent households (youth-based grandchildren prevalence rate), Washington, D.C. had a much higher rate than any state.

Twenty-nine states $(56.9 \%$ ) had rates of $6 \%$ and higher. In comparison to California's rate of $6.4 \%$, Southern states tended to have more children living with grandparents; Great Plains and Northwestern states had fewer. California and seven states accounted for $50 \%$ of the children living with grandparents nationwide (Blackburn 2000).

California prevalence rates. Children under age 18 made up about $26 \%$ of California's population in 1990 , with the proportion ranging from $16 \%$ to $34 \%$ in individual counties (table 1 ). Of the state's total population, children living in grandparent households were $1.7 \%$, with the proportion varying between $0.5 \%$ and $3.1 \%$ in individual counties. The numbers were highest in Imperial County at 3.1\%, and lowest in Mono and Marin counties, both at $0.5 \%$.

About $6.4 \%$ of all California children under 18 lived in their grandparents' homes and that rate ranged from $2 \%$ to $11 \%$ within all California counties (table 1; fig. 2). San Francisco and Imperial counties had the highest rates of children living with grandparents as their primary caretakers. In general, $77.6 \%$ of California counties had children living with grandparents at rates of $5 \%$ and above; $22.4 \%$ had rates of $2 \%$ to $4 \%$.

Rates and population density. The distribution of prevalence rates \pm the standard deviation (SD) of counties grouped by population density and/or regions, as defined by
TABLE 1. California children under 18 living in grandparent households

\begin{tabular}{|c|c|c|c|c|c|}
\hline County & $\begin{array}{c}\text { Total } \\
\text { population } \\
\text { by county }\end{array}$ & $\begin{array}{c}\text { Total } \\
\text { population } \\
\text { under } 18\end{array}$ & $\begin{array}{c}\text { Population } \\
\text { under } 18 \text { as } \% \\
\text { of total county } \\
\text { population }\end{array}$ & $\begin{array}{l}\text { Total number } \\
\text { children under } \\
18 \text { living with } \\
\text { grandparents }\end{array}$ & $\begin{array}{c}\text { Children under } 18 \\
\text { living with } \\
\text { grandparents as \% } \\
\text { of all children }\end{array}$ \\
\hline & & & $\%$ & & $\%$ \\
\hline Alameda & $1,279,182$ & 303,405 & 23.72 & 22,783 & 7.51 \\
\hline Alpine & 1,113 & 282 & 25.34 & 21 & 7.45 \\
\hline Amador & 30,039 & 5,656 & 18.83 & 292 & 5.16 \\
\hline Butte & 182,120 & 42,884 & 23.55 & 2,183 & 5.09 \\
\hline Calaveras & 31,998 & 7,937 & 24.80 & 489 & 6.16 \\
\hline Colusa & 16,275 & 5,003 & 30.74 & 203 & 4.06 \\
\hline Contra Costa & 803,732 & 202,088 & 25.14 & 10,823 & 5.36 \\
\hline Del Norte & 23,460 & 6,327 & 26.97 & 348 & 5.50 \\
\hline El Dorado & 125,995 & 33,245 & 26.39 & 1,333 & 4.01 \\
\hline Fresno & 667,490 & 209,036 & 31.32 & 13,037 & 6.24 \\
\hline Glenn & 24,798 & 7,560 & 30.49 & 353 & 4.67 \\
\hline Humboldt & 119,118 & 30,607 & 25.69 & 1,354 & 4.42 \\
\hline Imperial & 109,303 & 37,459 & 34.27 & 3,384 & 9.03 \\
\hline Inyo & 18,281 & 4,437 & 24.27 & 220 & 4.96 \\
\hline Kern & 543,477 & 170,987 & 31.46 & 10,841 & 6.34 \\
\hline Kings & 101,469 & 30,788 & 30.34 & 1,778 & 5.77 \\
\hline Lake & 50,631 & 12,093 & 23.88 & 708 & 5.85 \\
\hline Lassen & 27,598 & 6,823 & 24.72 & 288 & 4.22 \\
\hline Los Angeles & $8,863,164$ & $2,326,110$ & 26.24 & 176,466 & 7.59 \\
\hline Madera & 88,090 & 27,383 & 31.09 & 1,988 & 7.26 \\
\hline Marin & 230,096 & 43,936 & 19.09 & 1,192 & 2.71 \\
\hline Mariposa & 14,302 & 3,266 & 22.84 & 177 & 5.42 \\
\hline Mendocino & 80,345 & 21,952 & 27.32 & 1,068 & 4.87 \\
\hline Merced & 178,403 & 60,666 & 34.01 & 3,232 & 5.33 \\
\hline Modoc & 9,678 & 2,623 & 27.10 & 114 & 4.35 \\
\hline Mono & 9,956 & 2,434 & 24.45 & 54 & 2.22 \\
\hline Monterey & 355,660 & 97,951 & 27.54 & 5,901 & 6.02 \\
\hline Napa & 110,765 & 25,720 & 23.22 & 1,159 & 4.51 \\
\hline Nevada & 78,510 & 18,992 & 24.19 & 803 & 4.23 \\
\hline Orange & $2,410,556$ & 589,303 & 24.45 & 30,007 & 5.09 \\
\hline Placer & 172,796 & 45,226 & 26.17 & 1,992 & 4.40 \\
\hline Plumas & 19,739 & 5,039 & 25.53 & 160 & 3.18 \\
\hline Riverside & $1,170,413$ & 333,261 & 28.47 & 20,175 & 6.05 \\
\hline Sacramento & $1,041,219$ & 274,979 & 26.41 & 15,651 & 5.69 \\
\hline San Benito & 36,697 & 11,401 & 31.07 & 743 & 6.52 \\
\hline San Bernardino & $1,418,380$ & 439,223 & 30.97 & 25,927 & 5.90 \\
\hline San Diego & $2,498,016$ & 610,946 & 24.46 & 33,101 & 5.42 \\
\hline San Francisco & 723,959 & 116,883 & 16.14 & 12,408 & 10.62 \\
\hline San Joaquin & 480,628 & 142,250 & 29.60 & 9,659 & 6.79 \\
\hline San Luis Obispo & 217,162 & 47,531 & 21.89 & 2,257 & 4.75 \\
\hline San Mateo & 649,623 & 142,486 & 21.93 & 8,512 & 5.97 \\
\hline Santa Barbara & 369,608 & 85,887 & 23.24 & 4,575 & 5.33 \\
\hline Santa Clara & $1,497,577$ & 359,207 & 23.99 & 21,989 & 6.12 \\
\hline Santa Cruz & 229,734 & 54,704 & 23.81 & 2,439 & 4.46 \\
\hline Shasta & 147,036 & 40,411 & 27.48 & 2,009 & 4.97 \\
\hline Sierra & 3,318 & 869 & 26.19 & 44 & 5.06 \\
\hline Siskiyou & 43,531 & 11,641 & 26.74 & 521 & 4.48 \\
\hline Solano & 340,421 & 97,840 & 28.74 & 5,254 & 5.37 \\
\hline Sonoma & 388,222 & 95,776 & 24.67 & 3,989 & 4.16 \\
\hline Stanislaus & 370,522 & 113,371 & 30.60 & 6,600 & 5.82 \\
\hline Sutter & 64,415 & 18,403 & 28.57 & 1,025 & 5.57 \\
\hline Tehama & 49,625 & 13,515 & 27.23 & 792 & 5.86 \\
\hline Trinity & 13,063 & 3,448 & 26.40 & 150 & 4.35 \\
\hline Tulare & 311,921 & 103,137 & 33.07 & 6,555 & 6.36 \\
\hline Tuolomne & 48,456 & 10,895 & 22.48 & 456 & 4.19 \\
\hline Ventura & 669,016 & 182,986 & 27.35 & 10,811 & 5.91 \\
\hline Yolo & 141,092 & 34,004 & 24.10 & 1,653 & 4.86 \\
\hline Yuba & 58,228 & 18,453 & 31.69 & 1,034 & 5.60 \\
\hline Total & $29,760,021$ & $7,750,725$ & 26.04 & 493,080 & 6.36 \\
\hline
\end{tabular}

Source: U.S. Census Data 1990 - Population and Housing: Summary Total file 1C. 


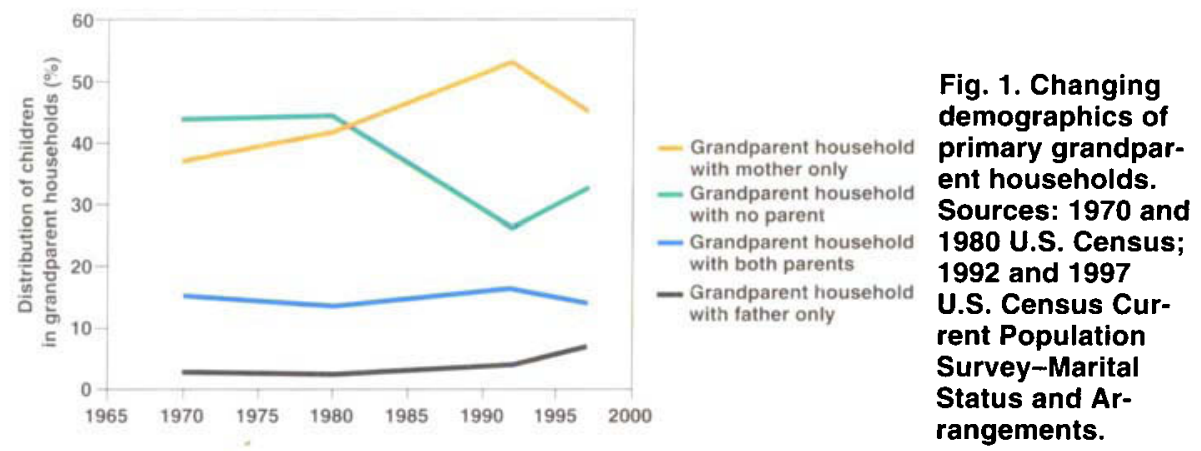

UCCE and the Division of Agriculture and Natural Resources, showed:

- Metropolitan counties with $>1$ million population $=6.0 \% \pm 1.89 \mathrm{SD}$

- Urban counties with $>100,000$ population $=5.6 \% \pm 1.19 \mathrm{SD}$

n Rural and semiurban counties $<100,000$ population $=5.0 \% \pm 1.31$ $\mathrm{SD}$

- Central Coast and South Region = $6.1 \% \pm 1.50 \mathrm{SD}$

- Central Valley Region $=5.6 \% \pm 0.79$ SD

- North Coast and Mountain Region $=4.3 \% \pm 1.06 \mathrm{SD}$

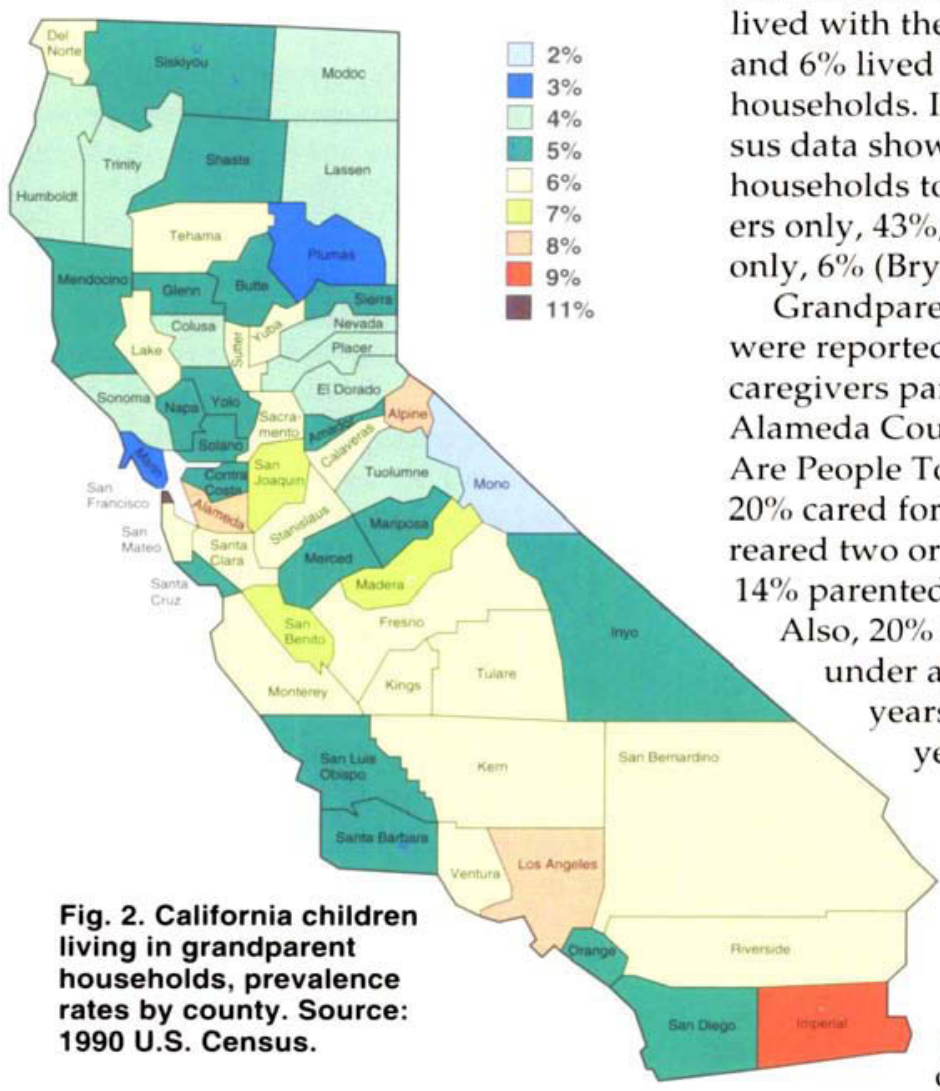

(DANR regions can be viewed at http://danr.ucop.edu/regional.htm.)

\section{Grandparenting conditions}

The four information sources revealed:

Household gender and responsibilities. Of the 22,783 children in Alameda County residing in grandparent households, $28 \%$ were white, $44 \%$ were black, $19 \%$ were Hispanic and $9 \%$ were categorized as other, according to the 1990 U.S. Census data.

About 9,330 (41\%) of these children, were under 6 years old. By household type, $48 \%$ of the children under age 6

lived with two grandparents, $46 \%$ lived with their grandmother only and $6 \%$ lived in grandfather-only households. In contrast, 1997 census data showed two-grandparent households to be $51 \%$; grandmothers only, $43 \%$; and grandfathers (Bryson and Casper 1999). Grandparenting responsibilities were reported by 98 grandparent caregivers participating in UCCE Alameda County's Grandparents Are People Too program. About $20 \%$ cared for one child; $57 \%$ eared two or three children; and parented four or five children nder age $5 ; 30 \%$ were 5 to 6 years; $22 \%$ were 7 to 10 years; $12 \%$ were 11 to 12 years; and $16 \%$ were over age 12 . These grandparents reported that $48 \%$ of their grandchildren had special problems, such as drug exposure, asthma, speech diffi- culties, hyperactivity, learning difficulties and discipline problems; some had lost grandchildren to Sudden Infant Death Syndrome.

Health concerns. At least $13 \%$ of these grandparents reported one chronic health problem; $29 \%$ had two; and $39 \%$ had three or more. Specifically, $61 \%$ reported painful arthritis/ gout; $52 \%$ had high blood pressure; $48 \%$ were overweight; $42 \%$ lived under very stressful conditions; $23 \%$ reported high blood cholesterol; $16 \%$ had heart disease; and 10\% reported diabetes. Additionally, $10 \%$ had food allergies, $12 \%$ said they had other environmental allergies and $9 \%$ had cancer.

Disrupted lives. Many grandparents in Oakland's Intergenerational Families Peer Counseling project, the Alameda County Grandparents Are People Too program, and the Sacramento conference said they needed continuing support to process the conflicting feelings they had toward their grandparenting responsibilities. The lives of some grandparents were disrupted and redirected; some felt that an outside force controlled their options, lives and futures. One Oakland grandmother, who cared for five grandchildren, said: "The babies need help. I need help too. No one seems to care about me. It is almost as if we are bound to do this thing. We have no say, no choice, no support, no financial assistance, no nothing. We are people too!"

Participants in the two interactive focus groups at the March 1996 conference in Sacramento expressed mixed emotions of anger, frustration and varying degrees of success and gratification. Some said families, neighbors and their communities sometimes perceived their grandparenting roles in ways that made them feel misunderstood, saddened and underappreciated. Some felt unfairly accused and were sometimes verbally attacked. Others said their parenting abilities were called into question and their motives at times were viewed as suspect. Some were told, for example: "It must be your fault"; "You messed up the first time and you will mess up again with these children"; "You are too old and senile to be trying to raise children"; 
"You are low-tech in a high-tech world"; or "You don't know what you are doing." Some grandparents also resented being told they were pushy and meddlesome, had bad attitudes and acted like know-it-alls. They were frustrated when told to back off and let the kids' parents do what they wanted with their grandchildren.

Emotional needs. Grandparents in the two focus groups at the 1996 conference in Sacramento said they needed help to cope with conflicting feelings and experiences. Many said they needed encouragement, moral support and validation. One said, "We don't need anyone telling us about the negatives. We know them because we live them." Some wanted to be appreciated for assuming difficult responsibilities to save their grandchildren from neglect, and perhaps even death. Others wanted to be told they were doing something right and to feel respected. As to their parenting abilities, they stated, "We are responsible! We need not feel disgraced as secondclass citizens. We do this because we care."

Some said they were having emotional conflicts with their children, which created negative feelings about their caregiving role. Some said, "We need help to try to separate the grandchildren we raise from the sins of their parents"; "Sometimes you feel so angry"; "We need to be friends to ourselves and find ways to release our frustrations"; "We need to learn how to get other people out of our business"; or "If people can't help and support us, then don't criticize us."

Education and training needs. At least $87 \%$ of the 98 grandparent caregivers who attended the Alameda County Grandparents Are People Too program stated that they needed help with child care, discipline, coping with teens, explaining the biological parents' absence and assisting grandchildren with homework. About 51\% wanted wellness and survival educa-

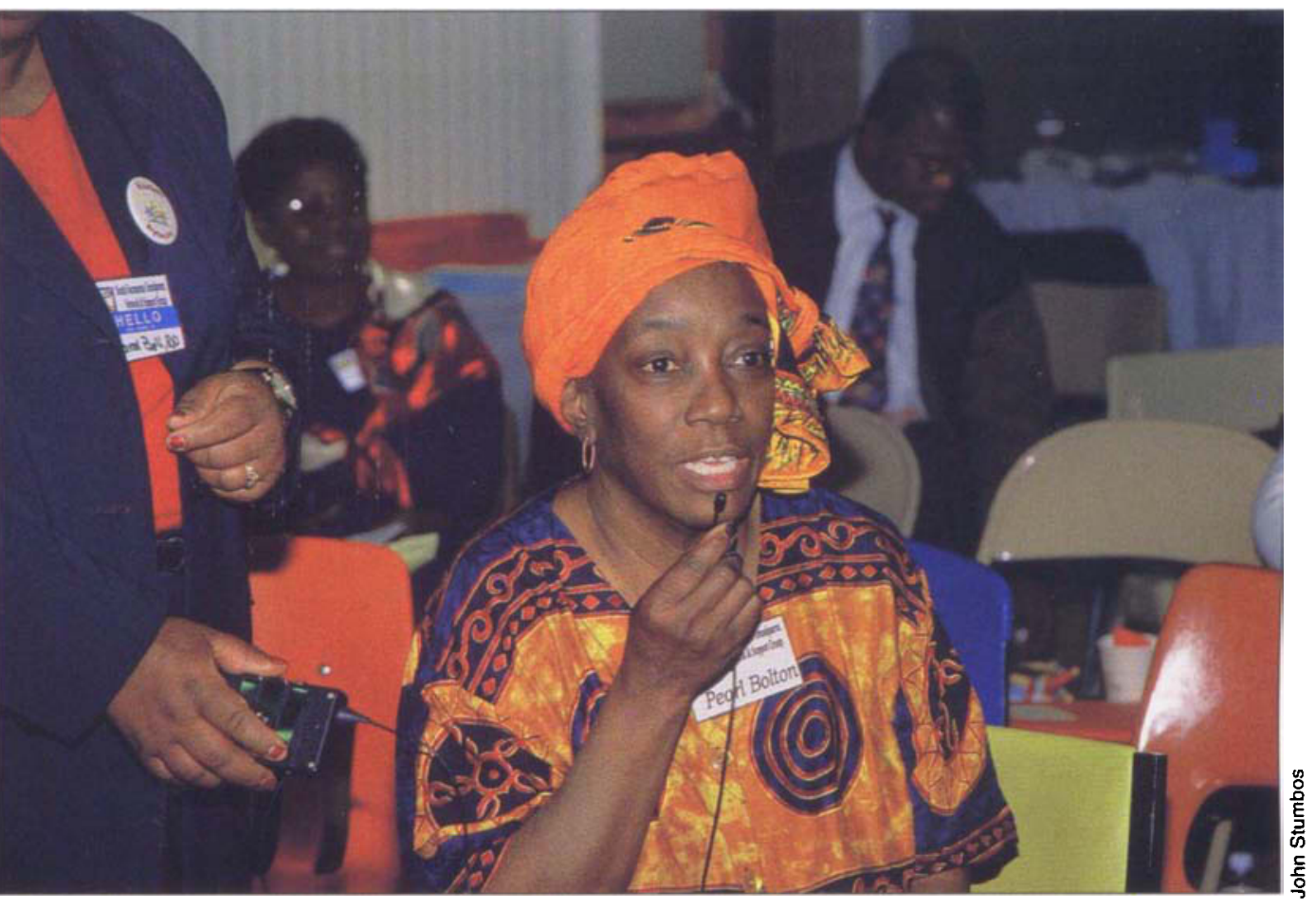

At the conference, grandparents such as Pearl Bolton spoke out about the stresses of caring for grandchildren. The children often have difficult physical and emotional needs, while their caregivers struggle with finances, legal matters and isolation.

tion in nutrition, low-cost meal planning, positive lifestyle modification, and money management skills to cope with financial hardship. Also, $33 \%$ said they needed advocacy service, respite care, and training on legal guardianship and grandparents' legal rights.

\section{Northern California survey results}

Other needs stated by 121 grandparents (from 24 counties) at the 1996 Sacramento conference included:

- Support groups to share experiences and to help impact public policy $(63 \%)$.

- Training to find and use resources $(58 \%)$.

- Opportunities to network with other grandparents $(56 \%)$.

- Changes in laws (52\%).

- Legal help (49\%).

- Respite care $(42 \%)$.

- Financial help $(35 \%)$.

- Help caring for children with special needs $(26 \%)$.

- Death counseling (25\%).

- Transportation (16\%).

Reasons for grandparenting.

When asked why they were raising their grandchildren, the grandparents reported that the parent(s) were:

- Abusing alcohol or drugs $(51.8 \%)$.

- Neglecting the children (33\%).

- Engaging in behavior unhealthy or dangerous for the children $(32.1 \%)$.

- Unable to care for the children $(29.8 \%)$.

- Physically abusing the children (19\%).

- Experiencing economic hardship $(18.5 \%)$.

- Serving jail or prison time $(14.9 \%)$.

- Deserted the children $(13.7 \%)$.

- Homeless $(8.9 \%)$.

- In ill health $(6.5 \%)$.

- Deceased $(4.8 \%)$.

Age of the children. About $60 \%$ of the children they parented were under age 10 . Of the children, $15 \%$ were under age 2; $28 \%$ were between 2 and 5 years; $17 \%$ were between 5 and 10 years; $33 \%$ were between 10 and 15 years old; and $7 \%$ were over age 16 .

Length of service. These grandparents had cared for their grandchildren, on average, for about 6 years. About $78 \%$ were rearing their grandchildren full-time; $17 \%$ intermittently; 


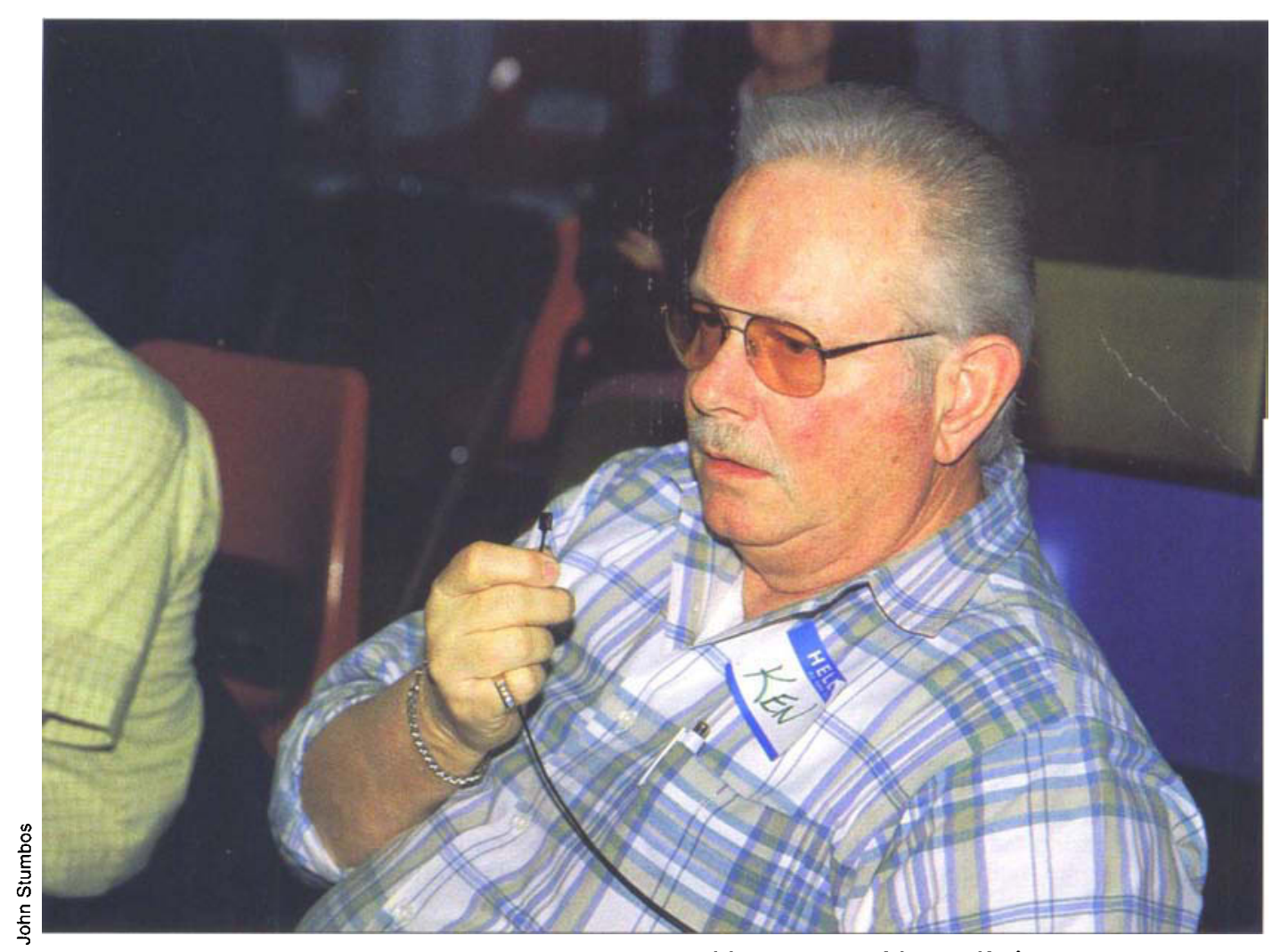

"We're scared to death that we're going to have to give him away," said grandfather Ken Lentsch, who cares for his 5-year-old grandson. Many grandparents said they need assistance navigating the legal system in order to obtain custody or visitation rights.

and $5 \%$ said they were expecting their grandparenting responsibilities to become long-term.

Grandchildren's needs. At least $52 \%$ of their grandchildren had physical, developmental and emotional problems. Among them, these problems included:

- Attention deficit or hyperactivity disorders $(38 \%)$.

- Severe learning disabilities (15\%).

- Emotional disorders $(11 \%)$.

- Drug exposure $(10 \%)$.

- Congenital disorders such as Down's syndrome and cerebral palsy $(7 \%)$.

- Respiratory and asthmatic conditions $(7 \%)$.

The remaining $12 \%$ of the grandchildren's problems included excessive anger and poor socialization, schizophrenic parents, kidney disease, nerve damage, a mother with Down's syndrome, or a combination of these factors.

\section{Role of substance abuse}

A 1998 report by the National Center on Addiction and Substance Abuse at Columbia University pointed to a growing problem of addiction among older females. The center estimated that almost 2 million women over age 59 were addicted to alcohol, and almost 3 million to prescription drugs.

Our research documented high incidences of multiple chronic diseases and stress among grandparent caregivers. Custodial grandparents were found to be more likely to have limitations in four of five daily living activities such as moving about in the home, day-to-day household tasks, climbing stairs, walking 6 blocks, household cleaning and working for pay (Minkler and Roe 1993; Minkler and Fuller-Thompson 1999).

Also, over $51 \%$ of the 121 grandparent participants surveyed at the Sacramento conference reported that they became primary caregivers because of substance abuse-related factors associchildren. ated with the parents of their grand-
UCCE Alameda County correlated California's 1991 substance exposure rates at birth by county (Vega et al. 1993) with the rates of children living with grandparents (data not presented). (The data was tested by a biostatistician from UC Berkeley Department of Nutritional Sciences.)

Correlations between substance exposure rates at birth and grandchildren living in grandparent households were significant at the $85 \%$ confidence level $(P=0.53)$.

\section{Dire circumstances}

Professional, scientific and academic communities should be concerned about grandparenting for a variety of reasons. The involvement of grandparents and other older kinship caregivers in the advancement and survival of the human species spans thousands of years. Grandparents caring for their grandchildren is not new. Threegeneration households and extended families have long enabled grandparents to play key roles in child rearing and to act as ongoing support in the daily lives of their grandchildren (Hawkes et al. 1998).

As women's participation in the work force increased in the United States, grandparents have played more prominent roles in caring for their grandchildren. In 1997, nearly 4.7 million grandparents lived in their childrens' homes, and grandmothers in particular, played prominent roles in providing child care while parents were at work or school (Bryson and Casper 1999).

The question germane to the grandparenting dilemma in the 1990s was not focused on traditional grandparenting roles. Rather, the public outcry was about the dire conditions under which some grandparent caregivers were performing primary parenting roles (de Toledo and Brown 1995). Their 
roles were more than just sharing the responsibilities for nurturing and support (Rompaey 1996). Our research and other studies show that grandparents often have no choice but to become primary custodians; many said they were trying to prevent their grandchildren from becoming wards of the courts.

\section{Planning for the future}

Grandparenting presents an urgent and significant challenge nationwide for human resource planners - to develop interventions on behalf of both the children and the caretakers at risk. Grandparenting problems and solutions in the 1990s were addressed in predominantly nonacademic settings, such as churches, senior centers and family resource centers. California and the nation lack a strategy to raise the priority level for research and program development funding. Our research can help to set priorities for the education, training and support needs of grandparent caregivers in California, and respond to some of the health and wellness concerns among grandparents and their grandchildren.

A programmatic framework to serve grandparents can be instituted through UCCE's established Family and Consumer Sciences programs. UCCE has proven experience in parenting education, nutrition education, chronic disease prevention and management, family resource and money management, child safety and self-esteem building. Minkler's research and coalition-building through the UC Berkeley School of Public Health led directly to the Brookdale Foundation-funded AARP National Grandparent Information Center in Washington, D.C. The efforts of UCCE have been less visible and have had less public policy impact.

The Adult Expanded Food and Nutrition Education Program (EFNEP) is a national vehicle through which UCCE could seek funds for children being reared by older caregivers. In early 1999, a group of UCCE specialists and family and consumer sciences advisors who conduct EFNEP pro- grams in California acknowledged the need for program planning around grandparenting. From preliminary discussions, eight counties around the state agreed to collaborate with the state EFNEP office to develop funds for a grandparent caregivers program. The goal was to reach out to grandparents, institute programs to reduce isolation and enhance nutrition, health and family well-being.

While this endeavor is still in its exploratory phase, the program idea is a natural extension of the Adult EFNEP concept of serving low-income and high-risk families. It also fits into DANR's strategic framework, "Human Resources Priorities: Human Health and Nutrition, and Economically Viable Families and Communities." Research and education would focus on how to effectively enhance the quality of life of California children raised by grandparents and other kinship caregivers, as well as the quality of the older caregivers' lives.

Future research should repeat the demographic study using 2000 census data, which will be available for analysis in 2002, to demonstrate changes in prevalence rates and potential client base in California counties during the 1990s.

M.L. Blackburn is Family and Consumer Sciences Advisor-Health and Nutrition, UC Cooperative Extension, Alameda County.

For research assistance, the author thanks Sandra Rivera, Alameda County Planning Department; Doris Calloway, Mark Hudes and Richard Barth, UC Berkeley; Arlene Saluter, U.S. Census Bureau; L.P. Consultants, Sacramento; Sondra Nathan, past Director, Oakland Department on Aging; grandparent participants in the Grandparents Are People Too project. Alameda County; Northern California conference participants; Marilyn Lovelace-Grant, Bay Area Catholic Charities, Oakland; and UCCE Alameda County support staff.

\section{References}

Blackburn ML. 2000. America's grandchildren living in grandparent households. J Fam \& Cons Sci 92(2):30-6.

Bryson K, Casper LM. 1999. CoResident Grandparents and Grandchildren. Census Bureau Current Populations Reports Series (May):23-198. Burton LM. 1991. Caring for children. American Enterprise (May-June):34-7.

Burton LM. 1992. Black grandparents rearing children of drug-addicted parents: Stressors, outcomes and social service needs. Gerontologist 32(6):744-51.

Chalfie D. 1995. The Prevalence and Policy Treatment of Midlife and Older People Living in Nontraditional Households. Washington, DC: AARP. p 25. de Toledo S, Brown DE. 1995. Grandparents as Parents: A Survival Guide for Raising a Second Family. New York: Gilford Publications. $322 p$.

Ginchild R. 1995. Grandparent caregivers face major challenges. Youth Law News (July-Aug):26-9.

Hawkes K, O'Connell JF, Blurton NG, et al. 1998. Grandmothering, menopause and the evolution of human life histories. Proceedings of the National Academy of Sciences 95(3):1336-9. Jendrek MP. 1994. Grandparents who parent their grandchildren: Circumstances and decisions. Gerontologist 34(2):206-16.

Minkler M, Fuller-Thompson E. 1999. The health of grandparents raising grandchildren: Results of a national study. Am J Public Health 89:1384-9.

Minkler M, Roe KR. 1993. Grandmothers as caregivers: Raising children of the crack cocaine epidemic. Family Caregiver Applications Series, Vol 2. Newbury Park, CA.: Sage Publications. $240 \mathrm{p}$.

National Center on Addiction and Substance Abuse. 1998. Under the Rug: Substance Abuse and the Mature Woman. New York: Columbia University. 211 p. www.casacolumbia.org/publications $1456 /$

Poe LM. 1992. Black Grandparents as Parents. Berkeley, CA: Lenora Madison Poe. Self-published. $109 \mathrm{p}$.

Rompaey JV. 1996. I Just Wanted to Be a Grandma: Parenting Grandchildren. AARP Grandparent Information Center. Summer Newsletter. p 11.

Saluter AF. 1994. Marital Status and Living Arrangements: Current Population Reports. Commerce Dept, Economics and Statistics Admin, Washington, DC. P20:484, p xii.

Vega WA, Kolody B, Noble A, et al. 1993. Profile of Alcohol and Drug Use During Pregnancy in California: Scientific Report. California Office of Perinatal Substance Abuse, Sacramento. 247 p. 